\title{
EL QUESO Y LOS FRIJOLES. El COSMOS DE UN JORNALERO SALVADOREÑO DEL SIGLO XX
}

\author{
Cheese and Beans. The Cosmos of a Twentieth-Century \\ SALVADORAN LABORER
}

\author{
Antonio García-Espada*
}

Resumen: En 1941, una investigación policial activada por una misteriosa denuncia contra un grupo de jornaleros salvadoreños evidencia un complejo entramado en la circulación de opinión pública entre clases sociales fuertemente dicotomizadas. La policía no logró formarse una idea clara del delito imputado a los jornaleros, que no obstante fueron obligados a cesar todas sus prácticas. Una lectura acuciosa del expediente evidencia el intento de los jornaleros de apropiarse de prestigiosas técnicas espirituales de la élite salvadoreña. A pesar del desenlace del proceso, la estrategia acabó triunfando y dando forma a una de las expresiones más originales de religiosidad vernácula.

Palabras clave: microhistoria, martinato, espiritismo vernáculo, religiosidad popular.

Abstract: At the end of 1941, the Salvadoran police, responding to a mysterious complaint, investigated a group of poor agricultural workers. The ensuing process reveals a complex pattern in the circulation of public opinion and social energy among strongly divided social classes. Although the police never completely understood the charges made against the laborers, their suspicious practices were forbidden. However, a thorough reading of the police report brings to light the workers' attempts to appropriate prestigious spiritual techniques used by the Salvadoran elite. In spite of the fateful ending of the police investigation, the laborers' strategy prevailed and shaped one of the most distinctive expressions of present-day vernacular religion.

Keywords: microhistory, Martinato, vernacular spiritism, popular religiosity.

\footnotetext{
*Antonio García Espada. Doctor en Historia por el Instituto Universitario Europeo de Florencia, Italia. Profesor investigador titular de tiempo completo del Centro de Estudios Superiores de México y Centroamérica de la Universidad de Ciencias y Artes de Chiapas, México. Temas de especialización: orígenes de la modernidad, expansión europea, literatura de viajes, religiosidad popular, estudios subalternos. Correo electrónico: antonio.garcia@unicach.mx. ORCID: https://orcid.org/0000-0003-1158-1018.
}

Enviado a dictamen: 17 de abril de 2018

Aprobación: 3 de octubre de 2018

Revisiones: 1 


\section{Introducción}

E nel Archivo General de la Nación de El Salvador se encuentra un informe de veinticinco páginas fechado el 9 de septiembre de 1941 y dirigido al director general de la Policía Nacional. ${ }^{1}$ El escrito está mecanografiado, con una impecable redacción y corrección gramatical. Contiene las diligencias llevadas a cabo por agentes del cuerpo en el municipio de Quezaltepeque, Departamento de La Libertad, y en la capital, San Salvador, a instancias de una denuncia anónima lanzada desde El Diario de Hoy, el rotativo nacional de mayor circulación en El Salvador, el 27 de agosto del mismo año. ${ }^{2}$ Las investigaciones policiales alentadas por el periódico contra "sujetos de dudosa honorabilidad" duraron seis días, y aunque el principal imputado resultó ser un tal Rafael George Huezo de 19 años de edad, jornalero de profesión y "adepto a la doctrina espiritista", el informe recoge interrogatorios realizados a otras catorce personas.

Desde luego, la policía salvadoreña de los años cuarenta del siglo XX no era el Santo Tribunal de la Inquisición, ni Rafael George acabó en la hoguera como Menocchio, el molinero del Friul italiano de las últimas décadas del siglo XVI. La intencionada alusión en el título de este trabajo ${ }^{3}$ a la obra clásica de Carlo Ginzburg, Il formaggio e i vermi (1976), apunta a una coincidencia aún mayor, a un propósito metodológico compartido con el gran historiador italiano que dedicó buena parte de su talento al estudio de fenómenos de la cultura oral, popular y subalterna a través de las fuentes producidas por letrados pertenecientes a los estamentos dominantes. Esta arriesgada apuesta por la investigación de la tradición oral a través de la página escrita aspira en último término a la identificación segura y contrastada de mecanismos significativos de la circulación de ideas y prácticas entre clases sociales fuertemente dicotomizadas - como en los casos salvadoreño del siglo XX y friulano del XVI-, así como a ensanchar la, por lo general, exigua cuota de agencia, autonomía y originalidad atribuida por las ciencias sociales a las clases subalternas en su confrontación con las clases dominantes.
Efectivamente, el caso de estudio salvadoreño presentado aquí muestra cierta incapacidad por parte de las fuerzas del orden público para identificar satisfactoriamente la naturaleza del delito investigado $y$, del otro lado, cierta habilidad de los imputados para desviar la atención y apartar la investigación de su objetivo específico. En este sentido, el método ginzburgiano se presta a su reutilización en un contexto, sin duda, tan remoto como el agro centroamericano de la primera mitad del siglo XX. Es este doble juego de espejos, la relación de continuidad/oposición entre escritura y oralidad o el igualmente difícil ensamble de metodologías de estudio cuantitativas y cualitativas - de historia y morfología - lo que hace pertinente el empleo de la sensibilidad característica del paradigma indiciario (Ginzburg, 1986), así como el tipo de descripción densa propia de la microhistoria. Esta enérgica tensión entre campos de fuerzas en buena medida definidos por oposición entre ellos espera ser mostrada claramente con la narración aquí presentada como una pelea librada enteramente en el campo de los símbolos, sin un claro vencedor y aún hoy lejos de haber sido resuelta.

\section{Primera parte}

\section{La acusación}

La noticia aparecida en el más importante diario del país lanzaba la acusación en su tercera página, con un gran titular de dos líneas que ocupaban el centro de la hoja, cubriendo de extremo a extremo las cinco columnas del rotativo, con una sarcástica declamación: "LOS ESPIRITISTAS DESPLUMAN A MEDIO MUNDO EN QUEZALTEPEQUE”. A renglón seguido, otro titular, menor pero también en letras capitales, rezaba: "SE RECIBEN DENUNCIAS". La nota en cambio es de lo más escueta, poco más de cien palabras embutidas en una pequeña caja en la que no aparece ningún dato del denunciante, no obstante calificado de "fuente fidedigna". Tampoco el contenido de la denuncia es claro, ni va más allá de un señalamiento mordaz dirigido contra "sujetos de dudosa honorabilidad quienes 
en altas horas de la noche se reúnen en cierta casa orillada". El final de la breve nota no deja lugar a dudas con respecto al fuerte sesgo del redactor -también anónimo-, la vehemencia con la que el periódico asume su condición de parte en la acusación contra los sujetos de la "casa orillada" y su connivencia con las fuerzas del orden público, "las autoridades", a las que solicita "una diligente investigación [para] así salvar el bolsillo y el juicio del público ingenuo". Claramente, el periódico excedía sus funciones, instrumentalizando su capacidad de generar opinión pública para usos partidarios, en beneficio de intereses de minorías y exclusivistas, echando mano de un código dogmático -grandes titulares-, sin mostrarse compelido a sustanciar con argumentos razonados el contenido de su denuncia

\section{Los investigadores}

La interpelación periodística fue atendida con gran celeridad. A las nueve horas de la mañana del día 4 de septiembre, dos agentes de la Sección de Investigaciones Especiales, el teniente Enrique Lemus y el agente ciento cincuenta y cuatro [sic], acompañados del secretario Horacio Rivas y, probablemente, de algunos agentes más sin nombrar, están en Quezaltepeque, ciudad situada a espaldas del volcán que da sombra a la capital San Salvador, concretamente en el arrabal del Guayabal, en la casa de Rafael George. Nada en el minucioso informe dejado por la policía salvadoreña da cuenta de la inmediatez con que fue identificado y localizado quien, a la postre, resultaría principal imputado y único condenado. Así, desde los primeros renglones del citado informe queda claro que la apariencia de atestado es fingida, que el informe mecanografiado es a lo sumo la reelaboración de un conjunto de testimonios $\mathrm{y}$, acaso, notas de campo que de manera simplificada y sintetizada pasan por alto información obtenida en el terreno que es descartada por irrelevante para -o irreconciliable con- el propósito del proceso.

Igual ocurre con el testimonio de los testigos o imputados. Sus declaraciones varían en extensión, pero la mayor parte de ellas reproducen una estructura discursiva, a todas luces fingida también pues, sin excepción alguna, aluden a los mismos asuntos, por lo general empleando las mismas palabras y siguiendo un orden expositivo prácticamente invariable. Se trata de interrogatorios hechos con base en un formulario fijo, igual para todos - a excepción de Rafael George, a quien se aplicó un número mayor y más diversificado de preguntas - y que, presuntamente, eran leídos a los declarantes para constatar su conformidad con una firma. Parece claro que el formato daba poco margen a las justificaciones, matices o intentos de apelación por parte de los imputados, en la misma medida que aumentaba considerablemente la capacidad de los investigadores de controlar los testimonios.

Tampoco el informe da cuenta de las condiciones en que fueron llevados a cabo los interrogatorios, tan sólo la hora en la que tuvieron comienzo. Catorce de los quince deponentes declararon entre los días 4 y 6 de septiembre separados por intervalos variables, aunque a menudo de no más de treinta minutos, lo que sugiere la posibilidad de que todos ellos estuvieran en espera, quizá en una misma sala, aguardando turno para ser interrogados. No obstante, ni leyendo entre líneas o a contrapelo, nada en el informe permite entrever el uso de la violencia o la coacción por parte de las fuerzas de seguridad del Estado.

\section{El delito}

Ni el cínico paternalismo de la nota periodística ni el tono altamente estilizado del informe policial permiten establecer de manera clara cuál es la naturaleza del delito denunciado y diligentemente investigado. A este fin es necesario recurrir a un tercer documento. ${ }^{4}$ Se trata de un escueto oficio fechado el 6 de octubre de 1941, firmado por el ministro de Gobernación José Tomás Calderón y dirigido al director general de la policía en relación con el caso de Quezaltepeque y con la orden, un tanto vaga, de "cesar tales prácticas [actividades de espiritismo en el Guayabal] toda vez que constituyen un medio de explotación, engaño y estafa". La severa sentencia, empero, no guarda una relación lineal con las diligencias llevadas a cabo por los agentes especiales de la policía salvadoreña. 
De acuerdo con el minucioso informe redactado por los investigadores, a todos los declarantes se les preguntó si eran "adeptos a la doctrina espiritista", y a partir de ahí tuvieron que dar cuenta, bajo diversas formulaciones, de "la cantidad de dinero [que] se exige que se deje", si no "se les cobra ni un centavo" o, incluso, si "se ofrendó alguna limosna en efectivo". Las respuestas fueron desde la negación absoluta, a fórmulas de compromiso con las que, quizá, el interrogado no hacía sino intentar satisfacer las expectativas -iexigencias?- de la policía, como: que "[sólo] se les instruye a que hagan caridad entre los necesitados" o "que las personas que de su voluntad deseen dejar limosna lo hacen [...] y las limosnas que dejan, que ascienden a pocos centavos, sirven para comprar flores e incienso", a lo sumo, para "el pago de casa y luz eléctrica". De las transacciones en efectivo que la policía pudo comprobar, ninguna superaba los cincuenta centavos de colón, siempre en concepto de limosna, para fines legítimos, nunca lucrativos.

A continuación, los agentes trataron de averiguar en qué consistían las "actividades de espiritismo" y si los practicantes contaban para realizarlas con alguna autorización. En efecto, no existía tal permiso oficial. Sin embargo, varios entrevistados argumentaron contra esto que "no es necesario ya que la Constitución Política de la República da facultades para la libertad de cultos", y así lo reconocían los propios investigadores al final de su informe en alusión al "artículo doce de la Constitución que da libertad de cultos".

Pero los desaciertos de la policía en la persecución de omisiones jurídicas o de fraudes pecuniarios provenían de una confusión aún mayor. Todo el proceso había sido desde el principio dirigido contra "espiritistas" y los cuestionarios de la policía comenzaban con la misma pregunta, la única que aparece en todos los testimonios: si "efectivamente pertenece a la doctrina espiritista" y "qué finalidad persigue dicha secta". Sin embargo, de los catorce individuos del Guayabal llamados a testificar, sólo seis reconocieron su adscripción al espiritismo. El resto lo negó y, en su lugar, cinco se declararon pertenecientes a la secta de los "temblorosos" y tres a la de los "sabatistas"; es decir, a las Iglesias pentecostal y adventista "vulgarmente llamados así por el pueblo", la primera porque "hacen contorciones [sic] cuando celebran su rito y el Espíritu Santo viene a ellos" y la segunda porque "la finalidad que persigue la secta es hacer guardar el sábado como día de fiesta, pues se basan para ello en que Dios hizo el mundo en seis días comenzando desde el domingo y dejó el sábado para descansar".

Hay motivos más que suficientes (lo veremos a continuación) para suponer cuando menos un grado aceptable de conocimiento, si no de familiaridad, con dicha doctrina espiritista por parte de los agentes especiales de la policía. Sin embargo, en su informe el único atisbo de justificación a tan llamativa confusión se basó en "que su fe [la de temblorosos y sabatistas] está puesta en que el Espíritu Santo los ilumina para seguir en esta vida material la verdadera senda que los guía hacia Dios por medio del mejoramiento espiritual". El recurso era ciertamente pobre y su descuidada formulación da cuenta de la indiferencia con que la policía contempló las, por otra parte, notorias diferencias entre espiritistas y pentecostales o entre espiritistas y adventistas. Aquí, de nuevo, todo apunta a que el propósito último de la investigación, la presunción que convertía en imputados a un grupo determinado de personas, iba más allá de las formalidades y contenidos doctrinales de unas $\mathrm{u}$ otras sectas e incluso más allá de su conformidad con la legislación vigente.

\section{El anticomunismo}

Con toda probabilidad, las cuestiones más apremiantes y las más seriamente afrontadas por los investigadores de la policía fueron los "asuntos de carácter político o subversivo". Es significativo que la pregunta no aparece formulada en ninguno de los atestados, pero "el tema" se menciona en todos y cada uno de ellos. A juzgar por la elección de las palabras y la reiteración de fórmulas, es probable que las respuestas de los encausados reprodujeran literalmente las preguntas de las autoridades: "ningún asunto de carácter político o subversivo" (tres veces); "no se trata ningún tema político ni de índole subversiva" (seis veces); "nunca 
se tratan de cosas políticas ni subversivas ni que sean atentatorias contra el Supremo Gobierno" (cuatro veces); "no se desarrollan temas de índole política ni atentativas [sic] contra el estado de cosas actual que hagan con la intención de alterar el orden social" (dos veces). Otro tanto ocurre en relación con si "las sesiones se celebran a puerta abierta", cuestión que casi la totalidad de los declarantes ratificó excepto los espiritistas, quienes tuvieron que reconocer que "celebran a puerta cerrada porque el dejarla abierta va en perjuicio de los médiums".

Este tipo de "confesiones" aparecen en los últimos tramos de las declaraciones de todos los imputados. Pero antes de llegar a este punto, los policías utilizaron técnicas más tortuosas, con preguntas mucho menos diáfanas y destinadas a desentrañar cuestiones de orden organizativo. En algunos de los testimonios se percibe claramente la huella de este tipo de inquisiciones, como cuando los declarantes se refieren a la "directiva" bien para negar su existencia o bien para dar detalle de alguno de sus nombres. Más comunes son las alusiones a "cuántos y quiénes asistían" a las sesiones o reuniones, a veces seguidas de fórmulas — un poco artificiosas, quizá - como "acordándose el deponente de [fulano o zutano]". Ninguno de los interrogatorios se resolvió sin la obtención del nombre de otro implicado, ya fuera en condición de organizador, colaborador, tesorero, simpatizante o lo que fuera. De nuevo, nada en el exquisito tono empleado en el informe de la policía nos autoriza a pensar en delaciones forzadas obtenidas mediante tortura o intimidación.

Tras la diligente persecución, el propio informe de la policía tuvo que reconocer que las pruebas o indicios que incriminaban a los investigados del Guayabal como conspiradores, o tan siquiera como opositores políticos, eran insuficientes. Al final, el último argumento en su contra fue que "los primeros [los espiritistas] se hacen sospechosos por sesionar a puerta cerrada" y nada más. Pero isospechosos de qué? Veamos qué nos dicen la fecha del documento y el contexto histórico a ella asociada.

En septiembre de 1941, al frente de la presidencia de El Salvador estaba por noveno año consecutivo el carismático general Maximiliano Hernández Martínez. Su mandato habría de ser el más largo de todo el siglo XX salvadoreño, y dio comienzo, a través de una larga sucesión de juntas y presidentes, a uno de los regímenes militares más estables y duraderos de toda la América Latina, hasta su derrocamiento en 1979, tras casi cincuenta años. El golpe de Estado que llevó al poder al general Martínez en diciembre de 1931 fue normalizado en 1935 mediante un plebiscito al que concurrió en condición de candidato único y del que obviamente salió victorioso. En 1939, en cambio, se prescindió de la fórmula electoral y su reelección fue hecha mediante decreto legislativo, por lo que se quebrantó la legitimidad constitucional vigente: en concreto, el artículo 148 de la Carta Magna de 1886. A partir de entonces, el general conoció las primeras formas de oposición frontal dentro de su propio partido, el Propatria, con importantes deserciones e intentos de golpe de Estado (Parkman, 2003).

Si bien hasta ese momento la mayor parte del gobierno del general Martínez había transcurrido bajo el estado de sitio, con importantes limitaciones a libertades políticas y civiles, la fuerte oposición interna alentada por el decretazo de 1939 tuvo la facultad de reactivar poderosamente "el clientelismo político, un control territorial exhaustivo de la población, la formación de un partido hegemónico y la exitosa incorporación de civiles a las tareas de vigilancia y espionaje" (Monterrosa, 2018: 88) y, por supuesto, la ideología dominante del régimen: el anticomunismo.

El anticomunismo de Martínez demostró ser el gran punto de convergencia de los sectores sociales más poderosos e influyentes de El Salvador -la Iglesia católica entre ellos- y el siempre vigilante gobierno de Estados Unidos. Totalmente consciente de ello, ante las nuevas dificultades de 1939, Martínez agitó el fantoche con desparpajo, aprovechando toda oportunidad que se le brindara para afirmar en privado o en público que "el peligro subsiste en condiciones cada día más difíciles para su persecución. Es insensato pensar que no haya gérmenes de comunismo en ningún conglomerado humano. Lo que aconseja la higiene política es no perder de vista esta verdad" (Monterrosa, 2018: 87). En este 
mismo contexto, Martínez dejó firmemente asentada la idea que habría de convertirse en principal vector discursivo de todo el siglo XX salvadoreño, la idea que armó la monstruosa guerra civil de la década de los ochenta y que aún hoy tiene dividida a buena parte de la sociedad salvadoreña (Castellanos, 2001).

Se trata del levantamiento armado del 22 de enero de 1932, apenas un mes después del asalto al poder de Martínez, que fue correspondido por el general con una violenta represión que pudo dejar entre diez mil y cuarenta mil muertos. El levantamiento tuvo lugar en el occidente del país, entre el empobrecido campesinado que a las alturas de 1930 experimentaba los más duros rigores de liberalización económica de finales del siglo XIX -privatización de tierras, imposición de trabajo forzado y criminalización de las últimas formas de organización e idiosincrasia indígenas- y la dedicación casi exclusiva al monocultivo del café. Su caracterización como levantamiento comunista puede que fuera un tanto exagerada, pero era a la vez la estrategia más efectiva para amansar a la bestia estadounidense que, precisamente, había sacado sus garras ante el inaceptable golpe de Estado dado en su "patio trasero" por el general Martínez (Ching, 2013). Así que, más allá de la verdad, la mentira y las posibilidades efectivas de corroborarlas, pronto se convirtió en un axioma conveniente para todos. Desde entonces -ihasta nuestros días!- la derecha salvadoreña gusta de proclamar El Salvador como "la tumba del comunismo en América", mientras que la izquierda no está menos orgullosa de ubicar en el "paisito" la primera revolución bolchevique de la historia americana (Alvarenga, 1996).

La policía de Martínez sacó a la calle su miedo a los levantamientos, especialmente en el agro y entre los más pobres, como en 1932. La búsqueda de comunistas en el Guayabal de Quezaltepeque pudo haber sido una de las principales razones que animaron la diligente investigación policial llevada a cabo en septiembre de 1941 o al menos proporcionó la estructura y rapidez de la respuesta, la impecabilidad del proceso, la profesionalidad de sus empleados. Aun así, la policía no encontró prueba alguna contra los "individuos deshonestos de la casa orillada" ni pudo incriminarlos por falta de orden político, y mucho menos armado. Ahí no estaba el delito.

\section{El veredicto}

En realidad no hubo una sentencia como tal, tan sólo una serie de oficios internos, como el mencionado anteriormente, que circularon entre el ministro de Gobernación y la Policía Nacional y que bastaron para zanjar todo el asunto, a modo de veredicto, obligando a los espiritistas del Guayabal a abandonar sus prácticas. El procedimiento en esta etapa final tampoco fue del todo claro. A las veinticinco páginas del informe que recogía las diligencias y conclusiones de la investigación policial, se le añadió un breve resumen dos días más tarde, el 18 de septiembre, sin firma, pero con membrete del Ministerio de Gobernación, donde se recomendaba actuar contra los espiritistas de Rafael George. ${ }^{5} \mathrm{La}$ respuesta del ministro José Tomás Calderón del día 6 de octubre, titulada "Que se evite explotación por medio del espiritismo", simplemente ordenaba el cese de tales actividades.

El 20 de octubre, un nuevo oficio firmado por el director nacional de la Policía, Juan F. Merino, informaba al ministro de Gobernación de la ejecución de sus órdenes. ${ }^{6}$ El inspector general de la Policía, Francisco Marroquín, había mandado al alcalde de Quezaltepeque citar a Rafael George para "notificarle que debe abstenerse de seguir celebrando sesiones 'espiritistas' porque se ha llegado a comprobar que con esa práctica explotan a la gente incauta; que, si continúa celebrando dichas sesiones, se le deducirán responsabilidades conforme a la letra 'E' del Art. 30 de la Ley Represiva de Vagos y Maleantes". El mismo oficio constata la actuación del alcalde de Quezaltepeque, quien certificó que Rafael George "quedó entendido, promete no volver a celebrar sesiones espiritistas y que en lo sucesivo se dedicará a trabajos lícitos".

Pero el mismo informe del 20 de octubre añadía algo nuevo. Las órdenes dadas al alcalde de Quezaltepeque por el inspector general de la Policía incluían también la actuación contra uno de los miembros de la "Secta 
Pentecostés" sin dar otra razón que por ir "contra la salud y el orden público". El citado individuo, Pedro Cristales, recibió la orden del alcalde, limitándose a responder que "queda entendido y firma". La instrucción no aparece en ninguno de los oficios anteriores girados entre Gobernación y la Policía y no iba más allá del apercibimiento contra Cristales en tanto dueño de una de las casas, situada en el Guayabal de la ciudad de Quezaltepeque, donde se celebraban de manera ocasional reuniones, particularmente escandalosas, eso sí, de los "temblorosos". El resto de las actividades de la secta pentecostés, sus reuniones en casas de otros adeptos, no aparecen por ninguna parte cuestionadas ni censuradas.

El proceso se solucionó, por tanto, distinguiendo entre tres niveles de incriminación dentro de una masa de acusados que al principio los investigadores no supieron muy bien cómo diferenciar. De hecho, las caracterizaciones de los miembros de cada una de las sectas que aparecen en el informe policial no son realmente portadoras de diferencias sustanciales. Todo el escrito está, en realidad, enunciado desde una posición que va de una especie de paternalismo indulgente a un desprecio latente. Y este mismo tono fue empleado con todos los entrevistados de Quezaltepeque, de unas y otras sectas. Así aparece en las conclusiones: "Los elementos que componen las tres sectas son jornaleros en su mayoría y así también las mujeres son de condición humilde, razón por la cual son fáciles de fanatizar [...] aunque podemos decir que son gente honrada que no registra hasta la fecha malos antecedentes".

Pero si queremos insistir en el rastreo de huellas que nos permitan entender los criterios seguidos por la policía a la hora de diferenciar unas y otras sectas, es cierto que pentecostales y adventistas emplearon por lo general un lenguaje mejor articulado y más asertivo. Fueron más vehementes en la proclamación de la libertad de cultos garantizada por la Constitución de 1886. Hicieron explícito su desafío a antiguas autoridades, actuando como conocedores de la legislación propia de una República laica: "no creen en la doctrina católica romana pues dicen que los sacerdotes con sus enseñanzas ambiguas mantienen el pueblo en el oscurantismo". Dijeron abiertamente que su propósito no era otro que extender su mensaje "mediante propaganda oral y escrita para atraer adeptos". "Temblorosos" y "sabatistas" se sabían poseedores de armas defensivas y de fuerza suficiente para resistir en sus posiciones.

Sin embargo, las conclusiones del informe de la policía no aluden tampoco a ninguno de estos episodios de autoafirmación a la hora de sustentar la distinción entre las tres sectas. Todo el peso de la argumentación exculpatoria recayó por el contrario en los avales externos proporcionados por los interrogados. Los pentecostales remitieron en primer lugar a José León Ramírez, "Pastor General de la Orden" originario de Nejapa -otro pueblo cercano a San Salvador-, quien llegaba a predicar cada jueves en una u otra de las casas de los distintos miembros de la secta y quien, efectivamente, contaba con un permiso oficial extendido por la autoridad central. Los pentecostales sacaron a colación otro nombre, "el Jefe de Línea Teniente Andrés Abelino Cruz", miembro de la Guardia Nacional y residente en Quezaltepeque, quien "pertenece a la orden y hasta celebró culto alguna vez en sus casas".

Los "sabatistas" por su parte fueron aún más convincentes a este respecto: "Este centro [el de Quezaltepeque] depende de la Sala Adventista que está en San Salvador y que dirige el señor Pedro Naygara, de origen extranjero y quien cada trimestre visita a esta ciudad para dar prédicas a los afiliados". La mención al ciudadano extranjero aparece de nuevo recogida en las conclusiones del informe, y ésta aparece como única justificación de la declaración de los "adventistas como la secta más depurada, cuya doctrina es más sencilla y tiene por base la caridad". Los pentecostales son, en estas últimas líneas del informe, tachados de "indeseables por extravagantes" y los espiritistas de "sospechosos por sesionar a puerta cerrada".

Fueron, por tanto, las credenciales de los avales externos dados por los interrogados el factor diferencial por excelencia. La simpleza del argumento esconde no obstante un componente esencial del sistema de garantías adoptado por las fuerzas de seguridad del Estado, con su contraparte en términos de confianza. 
La "honorabilidad" del teniente de la Guardia Nacional y del pastor debidamente certificado por la autoridad central y, en un grado aún superior, la condición de extranjero del "señor Pedro Naygara" bastaron para retirar la acusación, parcialmente, contra los pentecostales y, totalmente, contra los adventistas.

Pero, ipor qué se condenaba a los espiritistas de Rafael George? A los ojos de la policía, iqué los distinguía de los pentecostales de José León Ramírez y de los adventistas del extranjero Pedro Naygara? ¿Se trataba realmente de sus sesiones a puerta cerrada o más bien de su raigambre, su especificidad local, su relación con un entorno inmediato, su fatídica no "extranjeridad"? En la segunda parte se abordará con más detalle la cuestión de los condenados: quiénes eran Rafael George y su entorno.

\section{Segunda parte}

\section{Los interrogatorios de San Salvador}

Lo cierto es que los espiritistas intentaron una estrategia defensiva similar a la del resto de los imputados del Guayabal, sólo que no tuvo los efectos deseados. Todos los deponentes aseguraron que "el centro de Quezaltepeque depende de algotra [sic] sala de San Salvador". Y toda la defensa de Rafael George consistió en demostrar a la policía que su actividad era "sucursal, puede decirse, del centro Espiritista 'Santa Teresita' que queda en el barrio de Santa Lucía en San Salvador y que recibe instrucciones de María de Reyna [sic] encargada de la sala de San Salvador".

A diferencia de las menciones a Pedro Naygara de los adventistas y a José León Ramírez de los pentecostales, la policía quiso comprobar fehacientemente el aval dado por Rafael George, y el día 8 de septiembre, a las nueve de la mañana, los agentes se presentaron en la dirección de San Salvador dada por los espiritistas de Quezaltepeque.

La declaración de María Suarez Reina viene recogida en el informe aquí estudiado, ocupando casi dos páginas. Doña María dijo conocer a Rafael George, en quien reconoció ciertas dotes para la mediumnidad que le ocupaban cada quince días cuando recibía en su domicilio al joven quezaltepeco. Nada más. Doña María no tenía nada que ver con las actividades de George en Quezaltepeque y dejó a él sólo la iniciativa de haber compartido los conocimientos de ella recibidos con otros jornaleros del Guayabal, para cualquier fin.

En todo caso, la sala Santa Teresa regentada por doña María en el número 10 de la calle Costa Rica era perfectamente legal y probablemente prestigiosa. Estaba situada cerca de la basílica del Sagrado Corazón, en la actual calle Arce, uno de los barrios más elegantes de esos años y de los mejor conservados en nuestros días -dentro del altísimo nivel de deterioro general de todo el casco histórico de San Salvador-. Los "terroneros" sansalvadoreños -así conocidos por su fuerte apego a vivir en una ciudad continuamente destrozada por poderosos terremotos y erupciones volcánicas- desde antiguo han tenido entre sus favoritos al barrio donde doña María celebraba sus sesiones de espiritismo. La iglesia que da fama al barrio era entonces un caso singular de modernismo arquitectónico, igualmente comprometido con el neogótico y el art nouveau, construida con materiales futuristas, con láminas de fino acero soportadas por una estructura arácnida de madera, altamente resistente a sismos y temblores. El barrio es todavía hoy uno de los más propicios al ambiente bohemio del espiritismo "terronero".

El espiritismo en El Salvador hizo una entrada en verdad triunfal. Esta ideología, autodefinida como mitad ascético/chamánica mitad científico/racionalista, ya había alcanzado las mayores cotas de éxito imaginables en la Europa del último tercio del siglo XIX con la inclusión de materias sobre ciencia espiritista en el currículo de escuelas y universidades; en ella militaban algunos de los más altos e influyentes personajes de la época; por otro lado, se practicaban renovados autos de fe con escénicas piras ardientes de libros sobre espiritismo en la plaza de la catedral de Barcelona. En España desencadenó una reacción en varios aspectos similar al surgimiento del protestantismo, una especie de contrarreforma decimonónica de corte ultramontano que también tuvo múltiples y largas resonancias en toda Latinoamérica. 
En México, Centroamérica y el Caribe sin el espiritismo no se habrían dado ideas como la "Nuestra América” de Martí, poemas como los de Rubén Darío o figuras de la talla de Francisco I. Madero y Augusto C. Sandino. Evidentemente, en El Salvador se extendió como la pólvora y hasta con mayor celeridad que en otros países de su entorno, menos prósperos o simplemente con menor densidad de población. En el espiritismo salvadoreño participaron algunos de los más ilustres personajes de la primera mitad del siglo XX -Alberto Masferrer, Claudia Lars, María de Barata, Salarrué, Francisco Gavidia, Guerra Trigueros, etcétera- $y$, probablemente, el presidente de la nación (Casaús y García, 2005).

El general Maximiliano Hernández Martínez, también conocido como El Brujo de San Matías -su lugar de nacimiento-, nunca hizo pública su adhesión al espiritismo, pero sí a dos de sus principales secuelas, el vitalismo y la teosofía, en la que, antes del golpe de Estado, ejerció altos cargos directivos en una de sus principales logias, la Aletheia (Rodríguez, 2016: 86). De ello hizo auténtica ostentación después, a lo largo de su extenso mandato presidencial. En el Archivo General de la Nación salvadoreña se conservan transcripciones mecanografiadas de los discursos radiotransmitidos cada semana a toda la nación desde enero de 1940 a diciembre de $1943 .^{7}$ En una amalgama de ideas a veces difíciles de distinguir y expresadas de maneras no menos enigmáticas, el general Martínez buscaba edificar al pueblo entero, ser su maestro en el arte de llevar una vida mejor, para el Estado y para uno mismo. El contenido y sentido de sus pláticas cubre un amplio arco temático, pero en el fondo se limita a unos esquemas de pensamiento relativamente simples y predecibles.

El general admiraba a Annie Bessant, a los jesuitas y a Gengis Khan, y leía a Krishnamurti, Jinarajadasa y Napoleon Hill. Odiaba en cambio a Gandhi y a Freud, y reconocía como sus verdaderos maestros a "los eternos alquimistas y rosacruces, que los ha habido desde que el mundo es mundo", los a menudo también mencionados como "médicos invisibles". Desde las ondas emitió sus convicciones sobre el vegetarianismo, la abstemia y el naturismo, y llegó a poner de moda prácticas como usar aguas coloreadas para curar aflicciones del espíritu, caminar descalzo siempre que se pudiera, meditar en la reencarnación, así como el uso terapéutico de la botánica y el hermetismo esotérico en varias de sus muchas manifestaciones. Desde la radio proclamaba con ahínco su espíritu democrático y su firme defensa de la libertad total de cultos, aunque al final sale más a colación su apuesta por una filosofía del equilibrio, una especie de confucianismo centroamericano según el cual de la armonía en el microcosmos del cuerpo deriva todo el orden en el macrocosmos de la sociedad.

En su marcada apuesta por la sabiduría de las tradiciones milenarias, la teosofía, y antes que ella el espiritismo, habían abierto nuevos caminos a la crítica de la modernidad occidental, a su espíritu positivista y a su materialismo funcional. En El Salvador, y antes en países de su entorno como México, la primera víctima de esta especie de "primavera decolonial" fue sin duda la Iglesia católica (Parker, 2008). Qué duda cabe: el martinato fue uno de los grandes momentos secularizadores del largo proceso secularizador -de alguna manera aún hoy inacabado-, emprendido por la República salvadoreña desde prácticamente sus orígenes, aunque no es menos cierto que la Iglesia a estas alturas llevaba ya varios años de entrenamiento a la espalda en cómo sobrevivir sin el apoyo, y hasta con la oposición, del Estado. Y, por otra parte, el general Martínez se limitó a erradicar cualquier tipo de mención al catolicismo en sus manifestaciones públicas, mientras dejaba intacto el funcionamiento de la Iglesia en sus gestiones demográfico-económicas (Cardenal, 2001).

El caso es que el denodado esfuerzo de Martínez por alcanzar los oídos y los corazones de los salvadoreños tuvo recompensa. Una de las expresiones más interesantes para nuestro propósito es el testimonio de comunidades enteras de devotos organizadas en torno al culto de una suerte de santos populares -mejor conocidos en El Salvador como Hermanos Espirituales con nombres como Macario Canizález, Telesforo Sagastizado, Trinidad Huezo, Ernesto Interiano o Emeterio Ruano-, que a día de hoy siguen insistiendo en la relación personal de tales patronos con el general Maximiliano Hernández Martínez. A estos apócrifos 
santos locales se les atribuyen relaciones personales con el carismático presidente de los años treinta y cuarenta, como haber compartido con él mesas giratorias, sesiones de espiritismo y curaciones hechas por médicos invisibles.

Sin entrar en las posibilidades de demostración historiográfica de este tipo de memoria, éste es precisamente el ambiente que caracteriza el testimonio de Rafael George. Él dijo estar en contacto directo con gente importante de la capital que manejaba sofisticadas técnicas espirituales. De eso se servía a fin de considerarse autorizado para hacer uso de los conocimientos adquiridos en beneficio de sus vecinos jornaleros y familiares del Guayabal de Quezaltepeque, "adolecentes de enfermedad y el declarante poniéndose en trance hace que llegue el espíritu de Rafael A. Vista, que en vida fue médico y quien es el que receta medicinas a los pacientes que tiene en curación”. ¿Por qué no le creyó nadie, desde los agentes de la Policía Nacional al ministro de Gobernación?

\section{7. ¿Qué callaban la policía y el ministro?}

El descrédito de Rafael George se puso sobre la mesa ya en el propio informe de la policía. Al final del mismo, un curioso párrafo sorprende además por la repentina demostración de competencia en materia de espiritismo por parte de los investigadores: "es de extrañar que como según dijo [el joven Rafael] se pone en trance por concentración de sí mismo, cuando lo lógico sería que entrara en catalepsia mediante pases hipnóticos que le hiciese otra persona, como es costumbre hacerlo en otras sectas de la misma índole".

Nada a lo largo del informe anticipa una precisión y sutileza semejante en la captación del contenido técnico de las doctrinas o sectas investigadas. De hecho, el documento revela constantes confusiones en la distinción entre espiritistas y cristianos no católicos, aunque, como ya apuntamos, lo más probable es que se debiera a cierta dosis de indiferencia y falta de interés en aquello que, en principio, parecía el objeto propio de la investigación. Lo lógico aquí sería pensar que la mano que dio forma a esta sorprendente reflexión no fuera otra que la del secretario Horacio Rivas en vez de la del agente de la policía Enrique Lemus quien, supuestamente, narra en primera persona el informe policial. Cual Rustichello con Marco Polo, el secretario pondría en boca del agente perlas de sabiduría provenientes de su propia experiencia. Una experiencia que, además, sabemos de dónde puede proceder. Precisamente es Horacio Rivas quien aparece como el transcriptor comisionado del Ministerio de Gobernación para recoger por escrito buena parte de los discursos radiados semanalmente por el general Maximiliano Hernández Martínez; discursos plagados de teosofía, vitalismo, esoterismo y comunicaciones de los "médicos invisibles". A pesar de la apariencia de fría distancia y objetividad, los agentes, al menos uno, tenían ideas propias y bien formadas con respecto al marco de referencia del conflicto investigado.

Pero que la policía sabía más de lo que oficialmente dio a conocer en su informe queda demostrado también gracias a otra feliz coincidencia documental. No hay en todo el expediente de la policía, ni en los oficios intercambiados entre policía y Gobernación, así como en la denuncia lanzada desde El Diario de Hoy el 27 de agosto, nada que nos permita inferir ni mínimamente la identidad o alguna pista del posible denunciante o iniciador de tan diligente intervención por parte de las fuerzas del orden público. Sin embargo, justo en los mismos días en los que el ministro de Gobernación recibía informes de la policía y expedía órdenes en relación con los espiritistas del Guayabal de Quezaltepeque, mantenía una animada correspondencia con otro grupo de espiritistas, sin duda de una procedencia social muy distinta.

El 3 de octubre de 1941, tres días antes de la orden expedida por José Tomas Calderón contra los espiritistas del Guayabal, el mismo Ministerio de Gobernación admitía a trámite la solicitud de personería jurídica de la Escuela Racionalista Espirita Salvadoreña, la ERES. ${ }^{8}$ El procedimiento seguido en esa ocasión es también peculiar. El trámite había sido iniciado directamente con nada menos que el "Señor Presidente de la República”, el general Maximiliano Hernández Martínez, mediante una larga carta de seis 
páginas fechada el 16 de junio de 1941 y adornada con ciento veinticinco firmas. ${ }^{9}$ En línea con la confianza en sí mismos demostrada por el grupo a la hora de dirigirse al "Señor Presidente", la carta comenzaba recalcando que la asociación contaba con ilustres afiliados como los "pertenecientes al ejército, los señores Coronel don Víctor Manuel Sandoval y Capitanes Esteban Lemus González, Víctor Manuel Guerra y Florencio Bustamante Aceituno, así como otras personas verdaderamente cultas".

La distinguida asociación apelaba a la empatía del general Martínez para hacerle partícipe del "noble ideal que sustentamos y los altos fines que la Escuela Racionalista persigue", que no eran otros que "indicar el camino de la verdad por medio de la razón y los principios de la lógica". Con respecto al ideal, la carta daba un paso más allá en concreción anunciando que "este ideal, si es que la Divina Providencia de la Suprema Inteligencia nos ayuda a desarrollarlo, es el de ayudar a su ilustrado Gobierno, dando a conocer en todo el Mundo, sin adulación de ninguna clase y con un espíritu liberal, todos aquellos pasos seguros y certeros que dé a favor del pueblo" además de "elevar sus preces al Eterno Padre para que ilumine su conciencia y le dé más sabiduría".

La promesa debió seducir de inmediato al general Martínez, y tan solo seis días después, el 23 de junio, firmaba de su puño la autorización para ir adelantando el trámite solicitado por los racionalistas espiritas. ${ }^{10} \mathrm{La}$ petición hecha al presidente por la ERES para obtener la personería jurídica iba acompañada además de un importante ofrecimiento: "depurar el espiritismo en el país, tratando de contener el avance del animismo que por ahora se aprovecha de la ignorancia para explotar la creencia y la buena fe, tomando la ciencia espirita como el mejor patrimonio para vivir" (cursivas añadidas).

Los racionalistas espiritas proporcionan además otro valioso documento a esta investigación que, antes que nada, demuestra su proximidad y connivencia con altos funcionarios del Estado y su más que probable injerencia en el desenlace del caso de los espiritistas del Guayabal. El 26 de septiembre la directiva de la ERES hacía llegar, esta vez al ministro de Gobernación,
Luis Tomás Calderón, una misiva que citamos aquí en extenso. ${ }^{11}$ La declaratoria de los racionalistas espiritas llegaba a Gobernación ocho días después de la recepción del informe con las investigaciones de la policía y doce antes de la salida de la orden ministerial que prohibía a Rafael George ejercer el espiritismo entre los jornaleros quezaltepecos:

Se tiene conocimiento que en algunos lugares de la Republica han aparecido centros o personas que se dedican a las prácticas espiritistas, explotando la credulidad de gentes sencillas y valiéndose de prácticas censurables como son las de mixtificar el verdadero sentido moral y filosófico de tal ciencia espirita [...]. También han aparecido curanderos en todo el país que para mejor eficacia en sus labores de explotación se hacen aparecer como médiums espiritistas llegando al extremo de hacerse aparecer también como miembros de determinados centros establecidos en la capital [...]. ${ }^{12}$

Los racionalistas espiritas advertían, contra estos curanderos animistas que se "hacen aparecer como médiums espiritistas", que el mejor antídoto era "nuestra institución social en el plano que le corresponde de seriedad y merecedor de la atención de las altas autoridades de la República". Esta firme defensa de su monopolio sobre la "ciencia espiritista" les señala como más que probables instigadores en la sombra y parte activa en la instrucción del caso contra los espiritistas del Guayabal quezaltepeco. ¿Fueron por tanto los racionalistas espiritistas quienes determinaron la suerte del grupo de jornaleros en torno a Rafael George? ¿Fue éste el elusivo criterio que guió las minuciosas diligencias de las fuerzas del orden del Estado?

\section{Los jornaleros animistas}

Rafael George no aparece tratado en todo el informe de la policía de manera dura. Al contrario, la caracterización más directa que recibió fue: "el médium aunque jornalero es honrado”. De igual manera, como vimos, los demás espiritistas del Guayabal tan sólo fueron tratados 
como: "jornaleros en su mayoría [...] fáciles de fanatizar [...] aunque podemos decir que son gente honrada que no registra hasta la fecha malos antecedentes". La mayoría de los interrogados eran analfabetos y, de los espiritistas, sólo Rafael George era capaz de escribir su nombre. Excepto un sastre, un "comerciante en pequeño" y las mujeres que se declararon dedicadas a "oficios domésticos", el resto de los investigados fueron reportados como jornaleros. Era evidente que no se trataba de profesionales ni de propietarios, ni siquiera de campesinos o asalariados. Pero aquí la categoría "jornalero" parece estar funcionando además como una especie de indicador de carecer de una identidad social plenamente reconocible: algo así como lo que los antiguos romanos llamaban bárbaros o los cristianos, paganos.

Los espiritistas del Guayabal asumieron inmediatamente la posición de subalternidad adjudicada por losinvestigadores. No faltaron por lotanto respuestas torpes y a veces precipitadas. Alguno de los investigados, por ejemplo, se sintió obligado, tras responder "que en las sesiones no se trataban asuntos políticos ni subversivos", a añadir inmediatamente "que sólo se enseña la doctrina espiritista que en nada se diferencia de la católica". Ante la acusación mal entendida de "comunista", es interesante cómo el deponente se defiende de la sospecha de "idolatría" afirmando no su adhesión al "Supremo Gobierno", sino a la "Madre Iglesia". Y a buen seguro, la investigación dirigida contra los jornaleros del Guayabal acabó persiguiendo algo no del todo diferente a "un delito propio de los naturales, aunque aplicable también a negros, mulatos, mestizos y españoles, y que cubre un campo semántico amplísimo que abarcando desde la resistencia a la rebelión y de la superstición a la hechicería" (Piazza, 2016: 21, en su obra sobre la persecución de idolatría en Oaxaca entre los siglos XVI y XVIII).

A diferencia de los imputados que al final resultaron ser pentecostales y adventistas, los espiritistas basaron desde el principio toda su defensa en "aparecerse" lo más posible a la religión tradicional y dominante, el catolicismo, aun a costa de contradecir su adscripción alegada a una doctrina nueva pero prestigiosa y reconocida, el espiritismo. Las diferentes declaraciones de los imputados dan cuenta de sus titubeos a la hora de buscar el mejor paraguas. Así, mientras unos deponentes confesaban que el uso de las limosnas transadas era para "incienso y flores en honor de los espíritus que se presentan en la sala", otros prefirieron citar como beneficiario de las dádivas al mismísimo "Jesús Nazareno que es el guarda de la sala".

En general, todos los espiritistas interrogados dijeron con parecidas palabras que "la doctrina espiritista es la misma de Cristo", "que en nada se diferencia de la católica" o, a lo sumo, que "está basada en las enseñanzas de Jesucristo". A las torpes estrategias de legitimación de los jornaleros del Guayabal, la propia investigación añadía pruebas contundentes de que los imputados no actuaban "como es costumbre hacerlo en otras sectas de la misma índole". Por ejemplo, en clara imitación de doña María, la prestigiosa espiritista de San Salvador, Rafael George quiso incluir entre sus atribuciones como médium el dar "sesiones doctrinarias" para "fomento del espiritismo [a] unas veinte personas entre hombres y mujeres [...] los miércoles y los sábados entre las diez de la mañana y las trece horas". Sin embargo, a medida que se fueron acumulando testimonios de otros declarantes fue quedando claro que no había tal dinámica grupal en la sala del Guayabal o, si se daba, era de una naturaleza muy distinta.

Por ejemplo, uno de los nombres que George dio -idelató?- a la policía de los asistentes a sus pláticas doctrinales, Juan Rivera Zelaya, al ser interrogado afirmó ser en efecto "adepto de la doctrina espiritista y asistir a la sala que dirige el joven George". Pero más adelante el señor Zelaya, tras pormenorizar los detalles de sus padecimientos y su curación gracias a las técnicas empleadas por el joven George, añadió, quizá un tanto descuidadamente, que "desde que se curó ya no ha vuelto a llegar". Otros interrogados también dijeron que, en realidad, "no se daban conferencias de ninguna índole, sino que los espíritus por conducto del médium, señor George, recetaban medicinas a las personas que adolecían de alguna enfermedad" o que "en las sesiones no se han dado conferencias, sino que sólo consisten en oraciones elevadas en honor de los espíritus [...] hechas por medio de concentración general que hacen los presentes". 
La policía pareció comprender de inmediato que toda la actividad de los espiritistas del Guayabal giraba en torno a las dotes curanderas de George y a algún tipo de devoción colectiva difícil de desenmarañar. Con respecto al curanderismo, varios de los interrogados confesaron haber entrado en contacto con el espiritismo "por padecer de varios males físicos que no se los habían podido curar los médicos de esta ciudad", y uno añadió que "ni de San Salvador". Dichos males físicos iban de "una enfermedad de garganta [de la señora Juana Chicas]" a "un maleficio que ignora qué persona malintencionada se lo ha puesto [del señor Catarino Zavaleta]" o sencillamente "una complicación de males físicos a los que no hallaba curación [de la señora María viuda de Urías]".

Tales conceptualizaciones de la enfermedad pudieran ser portadoras de "una taxonomía diferente" que no distingue bien entre dolencia y enfermedad, que se desentiende de su origen biológico y trata el sufrimiento como una dimensión holística, como una experiencia global del ser "que se puede curar con las plantas" (Piazza, 2012: 22-23). En esto estuvieron de acuerdo todos los interrogados. No hubo uno que dejara de mencionar la botánica, como "base de todas las recetas" o como "única forma de curación".

Sin embargo, la reiteración de la palabra y su uso mecánico parece sugerir o bien el empleo de los mismos términos utilizados por los interrogadores —como en los casos referidos anteriormente en relación con vocablos como "subversivo" o "índole"- o, más probablemente, la resonancia de palabras en boga en esos días, reiteradamente utilizadas en los famosos discursos radiados a toda la nación de su señor presidente, conservados en el Archivo General de la Nación de El Salvador. ¿No se trataría de otro recurso legitimador, otro intento de entroncar con discursos prestigiosos provenientes de las élites letradas por parte de los jornaleros del Guayabal?

Así lo sugiere la desconfianza de la policía y la insistencia con que se propuso desentrañar el contenido de tan vaga proclama para averiguar que, en efecto, el uso dado por los jornaleros del Guayabal al término "botánica" excedía los límites del sentido común atribuido a la palabra. Las respuestas a los requerimientos de los interrogadores delataron que ciertamente se trataba de "brebajes hechos de raíces y cascaras", de "hojas de artemisa y cáscaras de pitos", pero también "a base de ojos". Uno de los interrogados dijo haber "sentido mejoría con la botánica", pero que después "desobedeció a los espíritus y se bañó, y cayó víctima del mismo mal, tan grave como antes lo tenía".

$\mathrm{Al}$ igual que las taxonomías esbozadas -envidias, maleficios o mal de ojo-, los remedios empleados por los jornaleros del Guayabal -sustancias de origen vegetal y animal, baños, compensaciones de frio y calor- hunden su lógica en el cosmos popular de usos interiorizados desde antiguo, de fuerte arraigo local y de acceso inmediato. Todos ellos, empero, mostrándose bajo nomenclaturas actualizadas e integradas en la economía simbólica creada por nuevos discursos de prestigio.

\section{El curandero y los espíritus}

La misma estrategia fue empleada en la defensa del joven George. El reconocimiento de Rafael como médium por parte de todos los interrogados, incluso de su "arrepentida" mentora María de Reyna, constituye su principal si no único anclaje a la doctrina espiritista. Ninguna otra de las imágenes capturadas por la policía sobre el funcionamiento del grupo de jornaleros del Guayabal reunidos en torno a Rafael se corresponde con la doctrina fundada en Francia por Allan Kardec en 1857 y vehemente representada en El Salvador por los racionalistas espiritas: ni la centralidad de la curación por medio de plantas, ni el protagonismo de enfermedades de todo menos científicas, ni la marcada adscripción al catolicismo, ni el incienso o las flores.

La policía no tardó tampoco en desmontar la coartada mediúmnica de Rafael: "es de extrañar que como según dijo se pone en trance por concentración de sí mismo, cuando lo lógico sería que entrara en catalepsia mediante pases hipnóticos que le hiciese otra persona". Esta versión simplificada de la entrada en trance, el recurso a oraciones colectivas y el empleo de remedios en extremo caseros alentaron las sospechas de los investigadores. El propio testimonio del joven George no hizo sino añadir nuevas pruebas a su propia 
acusación: "poniéndose en trance hace que llegue el espíritu de Rafael A. Vista, que en vida fue médico y quien es el que receta medicinas a los pacientes que tiene en curación". Precisamente, la importancia y centralidad del nombre de los espíritus invocados, aún más que las simplificadas técnicas mediúmnicas empleadas por el joven George, es indicador de un grado de autonomía mayor de los jornaleros del Guayabal con respecto a las prácticas generalmente asociadas al espiritismo "científico". Otros declarantes del proceso de Quezaltepeque constataron las visitas de otros dos espíritus: "la que en vida fue Refugio del Siglo" y "el que en vida fue Atanacio Ferrufino".

La búsqueda de pistas sobre alguno de estos tres nombres no ha dado aún los frutos esperados. Sin embargo, en el curso de la investigación se han encontrado hasta el momento cerca de una treintena de otros "espíritus de quienes en vida fueron" salvadoreños, mejor conocidos como Hermanos Espirituales (García, 2016a). Se trata de una suerte de santos apócrifos o patronos populares que normalmente funcionan como imágenes adoradas, veneradas, o como simples amuletos con propiedades específicas y diferentes facultades a la hora de beneficiar de una u otra manera a las personas vivas. Están, por tanto, dotados de biografías unas veces heroicas, otras chamánicas y aun algunas trágicas que, en cualquiera delos casos, sirven para reforzar las propiedades taumatúrgicas atribuidas a estos Hermanos Espirituales. A ellos se dirigen los devotos, amigos o necesitados mediante todo tipo de agasajos, regalos y hasta fiestas.

De su complejo y fascinante funcionamiento, el aspecto que más nos interesa en esta exposición es la manera en que establecen contacto con las personas vivas. Lo hacen por medio de especialistas no reglados que han adquirido el don de la comunicación gracias a cualidades inherentes, por lo general manifestadas a tierna edad y desarrolladas mediante determinadas técnicas ascéticas. En El Salvador se les llama "vasos", aunque no falta quien los conoce como "materias" e incluso "cajitas" o "mesas", denominaciones estas últimas mucho más extendidas en Guatemala y México.

A disposición de estos entrenados vasos hay un variado elenco de "espíritus de quienes en vida fueron", desde bandoleros locales en los años treinta, robinhoods injustamente ajusticiados o eminentes doctores y memorables curanderos, hasta la Lady Di princesa de Gales, el Sathya Sai Baba de la India o el propio general Maximiliano Hernández Martínez. Pero los hay también que son meras imágenes -de billetes de circulación corriente, de embalajes exóticos provenientes de la India, incluso fotos de Karl Marx retocadas con Photoshopcon nombres inventados. Entre estos hay quienes son capaces de comunicarse con deidades semíticas, egipcias y, también, precolombinas como el khukul y el ajaw en los casos de Macario Canizález en el occidente de El Salvador y de San Simón en el oeste de Guatemala, respectivamente (García, 2015). En estos casos se aprecia una continuidad inmediata con determinadas cosmotécnicas y antropotécnicas indígenas (Sloterdijk, 2012) supervivientes en estado muy precario y en aislados bolsillos de la geografía salvadoreña.

Estas deidades se encarnan durante intervalos de tiempo por lo general breves en los vasos e intervienen poderosamente en el desenvolvimiento cotidiano de sus vidas. Así, mediante el vaso dan a conocer formas de encarar la vida, la salud y la enfermedad, la felicidad y el sufrimiento, sancionadas por un uso prolongado. Los vasos dan voz y continuidad a multitud de remedios caseros, fetiches y cuentos antiguos. El mercado, el movimiento de personas interesadas en torno a la adquisición y venta de productos relacionados con este tipo de tecnología cultural, es considerablemente próspero y pujante. Más bello aún es el enorme desarrollo estético que sale a relucir en la confección de los objetos vinculados: imágenes, estatuas, candelas, símbolos, mandalas, dibujos, etcétera. Muy específicos y fuertemente anclados en el tiempo, el uso de materiales y colores, el empleo de efectos expresionistas, la distribución espacial de los objetos, están a menudo muy diferenciados de unos lugares a otros, aunque en último término estén sometidos a las posibilidades de reconocimiento por parte de sus usuarios. Todos estos saberes, el de los vasos, los mercaderes y los artesanos, por ejemplo, revelan una larga sucesión del culto ininterrumpido a deidades locales y a sus agentes humanos, con asombrosas similitudes, además de con 
expresiones florecientes en toda Centroamérica, y desde el Caribe al norte de México.

Es muy probable, por tanto, que, más que al espiritismo o al marxismo decimonónico, los Rafael A. Vista, Atanacio Ferrufino y Refugio del Siglo reportados por la policía de Martínez formaran parte del abigarrado panteón de deidades vernáculas conocidas en El Salvador como Hermanos Espirituales, y que las dotes mediúmnicas reclamadas por Rafael George fueran en realidad los nuevos ropajes con que a estas alturas se presentaba el antiguo vaso, materia o cajita de la tradición mesoamericana.

El profundo aturdimiento de los investigadores de la policía puede que se debiera a la incapacidad de reconocer la transformación que estaba teniendo lugar ante sus propios ojos de antiguas devociones, prácticas curativas y ecológicas. Los "jornaleros animistas" del Guayabal bien podían estar aprovechando los resquicios abiertos por las extravagancias metafísicas de su señor presidente, el retroceso público de la Iglesia, los últimos bríos de las pujantes doctrinas modernistas o, simplemente, los progresos de la tecnología fotográfica y fotostática. La policía, por su parte, anduvo tras resquicios de disidencia en cualquiera de sus múltiples manifestaciones, y al final no encontró otra cosa que sutiles indicios de estar ante "indeseables extravagancias", "incultos fáciles defanatizar", "carentes de moral" y "con cariz de timo". La nueva configuración de la cosmovisión del jornalero salvadoreño presentada a la policía a principios de la década de los cuarenta del siglo XX no fue entendida por ninguna de las instancias del Estado que participaron en este proceso. Su falta de comprensión, empatía o interés no fue, sin embargo, óbice a la hora de ordenar el cese total y la prohibición de todas las actividades de los jornaleros reunidos en torno al joven George, fuesen las que fuesen, y amenazarlos con aplicarles la "Ley Represiva de Vagos y Maleantes".

\section{Conclusión}

Irónicamente, la policía salvadoreña de nuestros días no procedería con tanta torpeza en el reconocimiento de Iglesias no cristianas - que en la actualidad alcanzan prácticamente al cincuenta por ciento de la población salvadoreña- ni de comunidades enteras organizadas en torno a célebres vasos -médiums, materias, etcéteraque mediante sus privilegiadas comunicaciones con multitud de Hermanos Espirituales proporcionan alivio y curación ante todo tipo de males y dificultades que aquejan a millares de salvadoreños de cualquier condición social y económica. De hecho, los policías salvadoreños de nuestros días son grandes "consumidores" de la inteligencia de estos vasos y del poder de sus santos, sobre todo los especializados en armas de fuego o los dedicados a la muerte (García, 2016b).

Las comunidades organizadas en torno a estos vasos y la devoción a las deidades a ellos asociadas ya no necesitan en nuestros días recurrir al espiritismo. Conservan alguno de sus conceptos y sus poses e incluso algunas imágenes de Allan Kardec o de Arthur Conan Doyle, por lo general, convertidos también en Hermanos Espirituales. En nuestros días, su autonomía es mayor y con el término "esoterismo" suelen contentarse para referir sus vernáculas concepciones de la salud, el bienestar y la imaginación del mundo a su alrededor. Acaso queda a las ciencias sociales la tarea de dar con un concepto más afinado de la cosmovisión del pueblo salvadoreño de hoy y del que una lectura atenta del proceso seguido contra Rafael George Huezo en septiembre de 1941, espero, sirva de esbozo certero.

\section{Notas}

${ }^{1}$ Archivo General de la Nación de El Salvador (en adelante AGNSV), Ministerio de Gobernación, Área Social, año 1941, caja 1. Mi agradecimiento a María Julia Flores por la localización de este expediente.

${ }^{2}$ Mi agradecimiento a Óscar Meléndez Ramírez por la identificación y reproducción fotostática del ejemplar.

3 Añadir algo de queso (de origen hispánico) a los frijoles (de origen mesoamericano) es el mayor deleite y aspiración culinaria de buena parte del empobrecido campesinado salvadoreño. Una aspiración semejante (humilde, mestiza y forzadamente prestigiosa) parece animar también a los protagonistas de esta pequeña historia. 
4 "Que se evite explotación por medio del espiritismo", AGNSV, Ministerio de Gobernación, Área Social, año 1941, caja 1 .

5 “Resumen”, AGNSV, Ministerio de Gobernación, Área Social, año 1941, caja 1.

6 "Informe sob/ explot. medio del esperitismo [sic]", AGNSV, Ministerio de Gobernación, Área Social, año 1941, caja 1 .

7 AGNSV, General Maximiliano Hernández Martínez, Serie 05, Pláticas doctrinales. Mi agradecimiento a Gerardo Monterrosa Cubías por su invaluable colaboración en la investigación de este fondo.

8 "Solicitud personería jurídica Escuela Racionalista Espirita Salvadoreña", AGNSV. Ministerio de Gobernación, Área Social, año 1941, caja 1.

9 "Escuela Racionalista Espirita Salvadoreña al Señor Presidente de la Republica", AGNSV, Ministerio de Gobernación, Área Social, año 1941, caja 1.

10 "Entrada No. 88 junio 24194l", AGNSV, Ministerio de Gobernación, Área Social, año 194l, caja l.

11 "Escuela Racionalista Espirita Salvadoreña al Señor Ministro", AGNSV, Ministerio de Gobernación, Área Social, año 1941, caja 1.

12 "Escuela Racionalista Espirita Salvadoreña al Señor Ministro", AGNSV, Ministerio de Gobernación, Área Social, año 1941, caja l.

\section{Referencias}

Alvarenga, Patricia (1996). Cultura y ética de la violencia. El Salvador 1880-1932. San José: Educa.

Cardenal, Rodolfo (2001). El poder eclesiástico en El Salvador: 1871-1931. San Salvador: Dirección de Publicaciones e Impresos.

Casaús Arzú, Marta Elena y Teresa García Giráldez (2005). Las redes intelectuales centroamericanas. Un siglo de imaginarios nacionales (1820-1920). Guatemala: F\&G Editores.

Castellanos, Juan Mario (2001). El Salvador: 1930-1960. Antecedentes históricos de la guerra civil. San Salvador: Dirección de Publicaciones e Impresos.

Ching, Erik Kristofer (2013). Authoritarian El Salvador. Politics and the Origins of Military Regimes, 1880-1940.
Notre Dame, Indiana: University of Notre Dame Press.

García Espada, Antonio (2015), "San Simón de Mesoamérica”. En Antonio García Espada (coord.), Religiosidad popular salvadoreña. San Salvador: Dirección de Publicaciones e Impresos.

García Espada, Antonio (2016a). "Historia de los Hermanos Espirituales y otros frutos modernistas de la religiosidad vernácula salvadoreña”. En Anuario de Estudios Centroamericanos, 42: 261-294.

García Espada, Antonio (2016b). "Los cumpleaños de San Simón. Etnografías salvadoreñas”. En LiminaR. Estudios Sociales y Humanísticos, XIV(2): 163-181.

Ginzburg, Carlo (1976). Il formaggio e i vermi. Il cosmo di un mugnaio del' 500. Turín: Einaudi.

Ginzburg, Carlo (1986). Miti, emblemi e spie. Morfologia e storia. Turín: Einaudi.

Monterrosa Cubías, Gerardo (2018). El Martinato: configuración, continuismo y herencia política. El Salvador 1931-1945. Tesis doctoral, Centro de Estudios Superiores de México y Centroamérica, San Cristóbal de Las Casas, Chiapas.

Parker Gumucio, Cristian (2008). "Mentalidad religiosa post-ilustrada: creencias y esoterismo en una sociedad en mutación cultural". En Aurelio Alonso (comp.), América Latina y el Caribe. Territorios religiosos y desafíos para el diálogo. Buenos Aires: CLACSO.

Parkman, Patricia (2003). Insurrección no violenta en El Salvador. San Salvador: Dirección de Publicaciones e Impresos.

Piazza, Rosalba (2012). El cuerpo colonial. Medicina y tradiciones del cuidado entre los maya-k'iche' de Totonicapán, Guatemala. Guatemala: Avancso.

Piazza, Rosalba (2016). La conciencia oscura de los naturales. Procesos de idolatría en la diócesis de Oaxaca (Nueva España), siglos XVI-XVIII. México: El Colegio de México.

Rodríguez Dobles, Esteban (2016). "Redes esotéricas en Centroamérica y Colombia (1904-1940). El caso de la sociedad teosófica". En Melancolía. Revista del Centro de Estudios sobre el Esoterismo Occidental de la UNASUR, l: 75-106.

Sloterdijk, Peter (2012). Has de cambiar tu vida. Sobre antropotécnica. Valencia: Pretextos. 